九州大学学術情報リポジトリ

Kyushu University Institutional Repository

\title{
Water Balance Evaluation and Water Quality Analysis of Paddy Field Irrigation System in Low Lying Area
}

Basri, Hairul

Laboratory of Irrigation and Water Utilization Engineering, Faculty of Agriculture, Kyushu University

Fukuda, Tetsuro

Laboratory of Irrigation and Water Utilization Engineering, Faculty of Agriculture, Kyushu University

Kuroda, Masaharu

Laboratory of Irrigation and Water Utilization Engineering, Faculty of Agriculture, Kyushu University

https://doi.org/10.5109/24268

出版情報：九州大学大学院農学研究院紀要. 43 (1/2)，pp.227-237，1998-11. Kyushu University バージョン：

権利関係: 


\title{
Water Balance Evaluation and Water Quality Analysis of Paddy Field Irrigation System in Low Lying Area
}

\author{
Hairul Basri, Tetsuro Fukuda and Masaharu Kuroda \\ Laboratory of Irrigation and Water Utilization Engineering, Faculty of Agriculture, \\ Kyushu University, Hakozaki, Higashi-ku, Fukuoka 812-8581, JAPAN \\ (Received, July 17, 1998 and accepted, August 7, 1998)
}

\begin{abstract}
This paper aimed to evaluate the water balance and to analyze the water quality of a paddy field irrigation system in low lying area. The water balance and concerning components were analyzed using a complex tank model consisted of paddy tank and drainage tank. The unknown return flow paranteters such as outflow terms from paddy fields and from drainage canal were able to be predicted using the tank model. The existence of the return flow in the system improves the efficiency of water use, but may have severe impacts on water quality in creek network. Therefore, the water quality is also necessary to be exanined. The status of water quality was clarified by evaluating both the net substance concentration and the net effluent load in the paddy irrigation system. The paddy fields showed the function of purification for total nitrogen (TN) except at periods of fertilizer application. Furthermore, the paddy fields had a tendency to follow the load form for electric conductivity ( $E C$ ) and chemical oxygen demand $(C O D)$. The formulas for predicting the net effluent loads in the area were also proposer in this paper.
\end{abstract}

\section{INTRODUCTION}

There are two objectives of agricultural water management i.e., (1) providing crop need to sustained high yield, and (2) reducing management loss of water operation in the system. Especially, the evaluation of efficiency of agricultural water management is important for anticipating water crisis on cropping development. The obtaining accurate informations of water balance are used for analyzing the efficiency of agricultural water management. In this study, the water balance and concerning components were clarified using a complex tank model consisted of two sub tank model i.e., the paddy field sub tank model and the drainage canal sub tank model. The model was proved capable in simulating the daily water cyclic in the system, particularly in performing reuse mechanism of return flow for yielding the high efficiency of water operation.

Although the return flow improves the efficiency of water use, it has severe impacts on water quality. Therefore, this paper concerns also to the water quality condition in the system investigated by evaluating the net substance concentration in resource in creek network as well as in return flow in drainage canal for finding the purification or the pollution degree of water quality. This paper also discusses the water quality phenomena on the normal days and on the restricted days during application of fertilizer by evaluating the net effluent load in the paddy irrigation system. 


\section{DESCRIPTION OF STUDY AREA}

The research was carried out on the area of 10.3 ha of the paddy irrigation system in Yamato Town, Fukuoka Prefecture, Kyushu, Japan as shown in Fig. 1. The Yamato Town is located in the side of the gulf of Ariake. The yearly average temperature is $16^{\circ} \mathrm{C}$ and
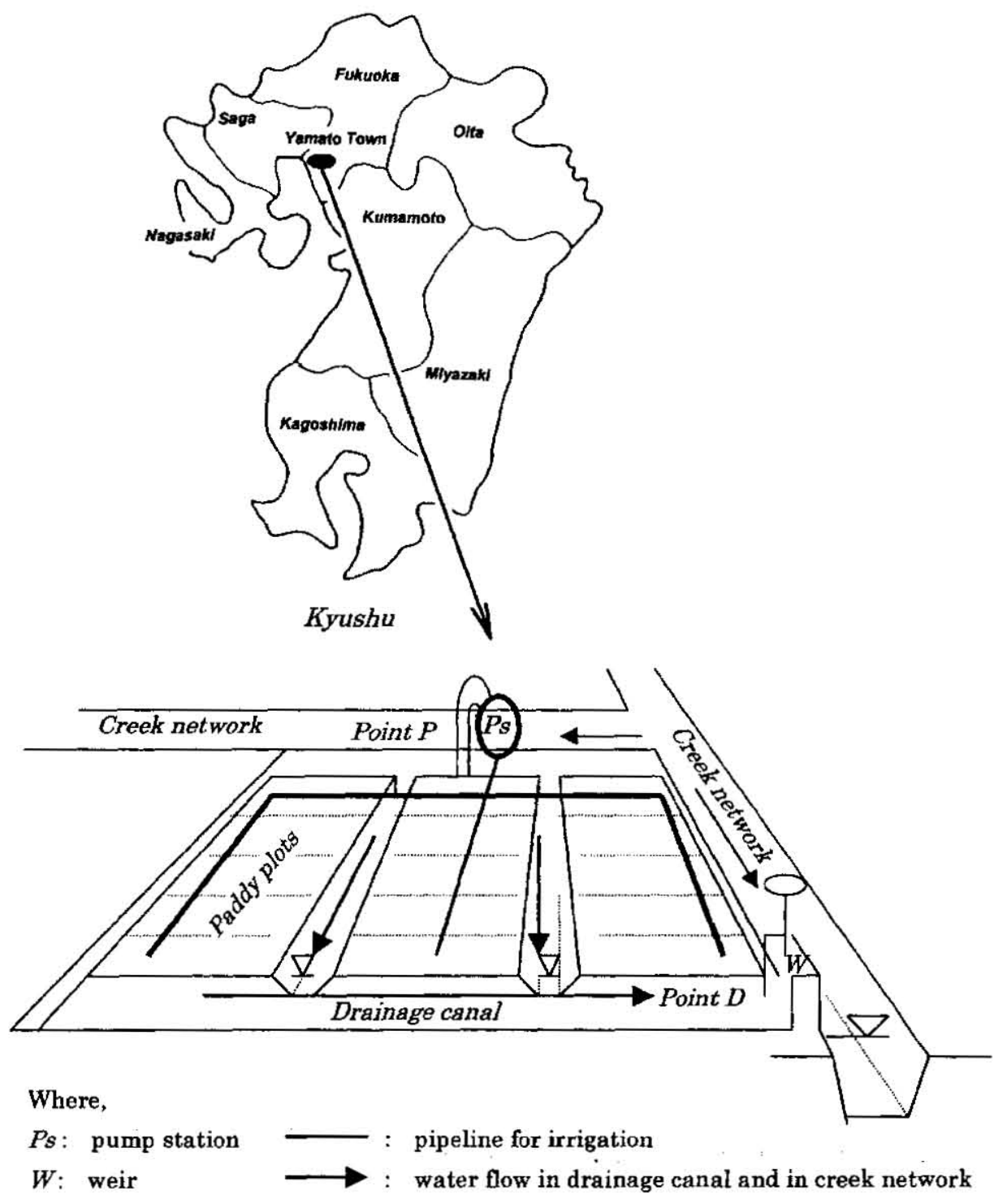

Fig. 1. Location of the study area and schematic representation of paddy irrigation system. 
the annual rainfall is approximately $1800 \mathrm{~mm}$. The latitude of the area is $33.08^{\circ} \mathrm{N}$. The geographical feature of the area is low lying and very flat. The altitude of the area is about $1 \mathrm{~m}$ above sea level. The area is, therefore, protected from sea tide by dike. The existence of creck network, as temporary water storage, is characterized as a part of water system for paddy culture in the area. The water level in creek network is usually lower than the paddy fields. Therefore, irrigation water to paddy fields from creek network is carried out using the pumping facility. The outflow from paddy fields into drainage canal (return flow) will reach the creek again. And this phenomenon will be affecting the water quality in the creek. As in usual, rainfall is not enough to support the growth of paddy crops, it is important to clarify the phenomena of recycle water and to evaluate the quality of irrigation water in the system. Measuring points of water quality in the area were chosen at the Point $P$ and at the Point $D$ as shown in Fig. 1. Point $P$ was located in the creek in which the irrigation water was supplied from the creek into paddy fields by pump. Point $D$ was located in the drainage canal in which the water quality of return flow from paddy fields was monitored.

\section{MODEL APPROACH}

\section{Water Balance in the System}

The water balance in the paddy irrigation system was analyzed using a complex tank model as shown in Fig. 2. The tank model was consisted of two sub tank model i.e., the paddy field sub tank model (namely, paddy tank) and the drainage canal sub tank model (namely, drainage tank). From Fig. 2, the water balance is expressed as follows.

paddy tank : $S p_{j}=S p_{j-1}+P_{j}+R p_{j}-Q_{\text {outp }}-E v p_{i}$ drainage tank $: S d_{j}=S d_{j}+$ Qoutp $p_{j}+R d_{j}-$ Qoutd $d_{j}-E v d_{j}$

Where, $j=$ present period; $S p_{i}, S d_{j}=$ water storage in paddy fields and in drainage canal at period $j$, respectively; $S p_{j-l}, S d_{j l}=$ water storage in paddy fields and in drainage canal at

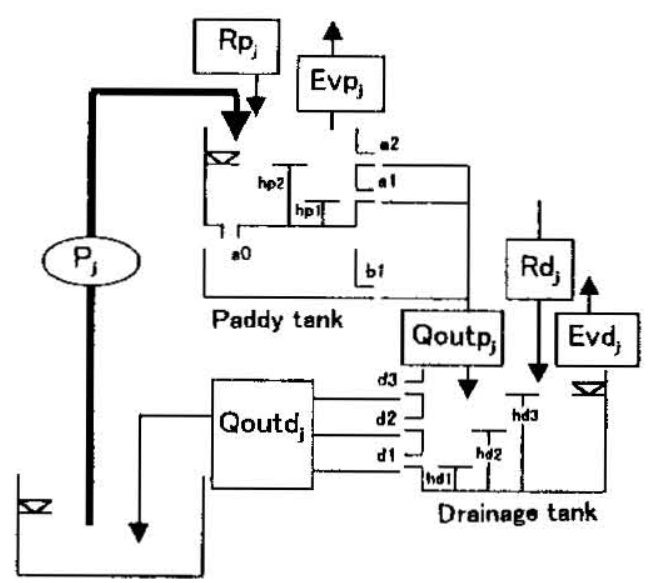

$\begin{aligned} & \text { Remark } \text { Components } \\ & \text { a2: } \text { surface runoff } \\ & \text { a1: } \text { seepage from levee } \\ & \text { a0: vertical percolation } \\ & \text { b1: deep seepage } \\ & \text { d3: drainage for emergency } \\ & \text { d2: drainage through weir } \\ & \text { d1: leakage through weir } \\ & \text { h: } \quad \text { water depth }\end{aligned}$

Fig. 2. A complex lank model. 
period $j-1$, respectively; $P_{j}=$ irrigation water by pumping facility from creek into paddy fields during the $j$ th period; $R p_{j}, R d_{j}=$ rainfall into paddy fields and into drainage canal during the $j$ th period, respectively; $Q$ out $p_{j}=$ water outflow from paddy fields into drainage canal during the $j$ th period; $E v p_{i}, E v d_{j}=$ evapotranspiration from paddy fields and evaporation from drainage canal during the $j$ th period, respectively; Qout $d_{j}=$ water outflow from drainage canal during the $j$ th period.

\section{Construction of Tank Model for Analysis}

As shown in Fig. 2, the terms of rainfall and irrigation water were input parameters for the paddy tank. In this area, the creek level was lower than paddy fields, then, irrigation water was supplied onto paddy fields by pumping facility from creek network through pipeline. On the other hand, the water flows from paddy fields into drainage canal and the evapotranspiration were considered as the output parameters from the paddy tank. The water flows from paddy fields into drainage canal and the rainfail in drainage canal were treated as the input parameters for the drainage tank. Furthermore, the water flows from drainage canal into creek network and the evaporation from drainage canal were dealt as the output parameters for the drainage tank.

Determination of parameter for height of tank holes

The initial values of parameters were previously set up according to actual farming period. In this case, the parameter $h p_{z}$ for the paddy tank was set up as high as the ponding depth of the paddy fields. Occasionally, the ponding depth was $50 \mathrm{~mm}$. Furthermore, the levee seepage of the paddy fields $h p$, was adjusted at $10 \mathrm{~mm}$.

The initial values of water depth were set up according to the average actual water depth in the drainage canal. In this case, the drainage for emergency $h d_{3}$ was set up as high as $350 \mathrm{~mm}$, the water depth as the drainage through weir $h d_{i}$ was set up at $175 \mathrm{~mm}$ and the water depth as leakage through weir $h d_{3}$ was set up at $75 \mathrm{~mm}$.

\section{Determination of hole parameter of tank}

The accuracy of predicted data was evaluated by finding the optimal combination of coefficients of the tank model. The hole parameters were decided by minimizing the objective function $Z$ as shown in equation (3). The procedure of optimization was taken by trial and error method. The obtained coefficients of the tank model are shown in Table 1.

$$
Z=\sum_{i=1}^{n}\left(h o_{i}-h c_{i}\right)^{2} / h o_{i}
$$

Table 1. Obtained Coefficients of Tank Model.

\begin{tabular}{cl}
\hline Paddy tank & \multicolumn{1}{c}{ Drainage tank } \\
\hline $\mathrm{a}_{3}=0.0140, \mathrm{a}_{\mathrm{t}}=0.2000$, & $\mathrm{d}_{\mathrm{l}}=0.0269, \mathrm{~d}_{2}=0.3300$, \\
$\mathrm{a}_{2}=0.6200, \mathrm{~b}_{\mathrm{t}}=0.0100$, & $\mathrm{d}_{3}=0.6300$, \\
$\mathrm{hp}_{1}=10 \mathrm{~mm}, \mathrm{hp}_{2}=50 \mathrm{~mm}$, & $\mathrm{hd}_{\mathrm{t}}=75 \mathrm{~mm}, \mathrm{hd}_{2}=175 \mathrm{~mm}, \mathrm{hd}_{3}=350 \mathrm{~mm}$ \\
\hline
\end{tabular}


Where, $n=$ number of data, $h o_{2}=$ the observed water depth, $h c_{i}=$ the calculated water depth.

Using the tank model, the unknown values of Qoutp $p_{j}$ in eq. (1) and Qoutd $d_{j}$ in eq. (2) were predicted. And the other components of water balance were obtained accurately for evaluating the reasonable water operation in the system.

\section{RESULTS AND DISCUSSION}

\section{Water Balance and Concerning Components}

The obtained results of water balance and concerning components are presented in Table 2. It shows that the irrigation water applied from creek into paddy fields is based on the growing stages of paddy crops. Kuroda et al. (1992) reported that, generally in the south west of Japan, the daily irrigation water is carried out which taking into consideration the growing stages of paddy crops as shown in Table 3. From Table 2, it can be seen that the irrigation water (pumped up water) for puddling and transplanting stage was around $20 \mathrm{~mm} /$ day and for other stages were around $7.80 \mathrm{~mm} /$ day in 1995 . In this area, irrigation facilities are operated by Land Improvement District, which is an

Table 2. Obtained Water Balance and (Concerning Components in Paddy Irrigation System (1995).

\begin{tabular}{|c|c|c|c|c|c|c|c|c|}
\hline \multirow{2}{*}{ Month } & \multirow{2}{*}{$\begin{array}{l}\text { Date } \\
\text { Avg.5 } \\
\text { days }\end{array}$} & \multicolumn{3}{|c|}{ Paddy Tank } & \multicolumn{4}{|c|}{ Drainage Tank } \\
\hline & & \multicolumn{3}{|c|}{$(\mathrm{mm} / \mathrm{day})$} & \multicolumn{4}{|c|}{ (mm/day) } \\
\hline \multirow{5}{*}{6} & & P & $R p_{i}$ & Evp. & Qoutp. & $\mathrm{Rd}_{1}$ & Evd: & Qoutci \\
\hline & 3 & 19.68 & 3.30 & 4.46 & 19.64 & 3.30 & 2.08 & 19.62 \\
\hline & 4 & 13.36 & 5.70 & 4.54 & 14.60 & 5.70 & 2.08 & 14.64 \\
\hline & 5 & 8.90 & 6.50 & 4.44 & 11.36 & 6.50 & 2.04 & 11.38 \\
\hline & 6 & 7.35 & 14.25 & 4.75 & 14.78 & 14.25 & 2.18 & 14.68 \\
\hline \multirow[t]{6}{*}{7} & 1 & 0.00 & 69.00 & 2.84 & 64.92 & 69.00 & 1.28 & 65.18 \\
\hline & 2 & 5.80 & 17.40 & 5.76 & 20.84 & 17.40 & 2.64 & 21.08 \\
\hline & 3 & 7.84 & 22.00 & 5.64 & 23.80 & 22.00 & 2.74 & 23.90 \\
\hline & 4 & 11.84 & 0.00 & 5.55 & 6.20 & 0.00 & 2.68 & 6.20 \\
\hline & 5 & 5.88 & 1.60 & 5.84 & 4.12 & 1.60 & 2.90 & 4.12 \\
\hline & 6 & 4.83 & 0.42 & 7.93 & 1.97 & 0.42 & 1.60 & 2.90 \\
\hline \multirow[t]{6}{*}{8} & 1 & 10.72 & 0.00 & 8.36 & 2.10 & 0.00 & 3.84 & 2.06 \\
\hline & 2 & 8.72 & 14.90 & 7.38 & 11.78 & 14.90 & 3.38 & 11.66 \\
\hline & 3 & 9.36 & 2.00 & 5.10 & 8.58 & 2.00 & 2.38 & 8.74 \\
\hline & 4 & 10.12 & 1.30 & 6.60 & 5.70 & 1.30 & 3.08 & 5.70 \\
\hline & 5 & 10.04 & 0.10 & 7.22 & 4.62 & 0.10 & 3.10 & 4.60 \\
\hline & 6 & 9.80 & 10.50 & 4.55 & 11.65 & 10.50 & 1.95 & 11.62 \\
\hline \multirow[t]{6}{*}{9} & 1 & 5.62 & 16.60 & 4.08 & 19.18 & 16.60 & 1.74 & 13.32 \\
\hline & 2 & 7.58 & 2.90 & 4.54 & 6.12 & 2.90 & 1.94 & 6.14 \\
\hline & 3 & 9.80 & 0.00 & 5.44 & 5.84 & 0.00 & 2.12 & 5.84 \\
\hline & 4 & 9.80 & 0.00 & 6.80 & 3.84 & 0.00 & 2.60 & 3.82 \\
\hline & 5 & 1.96 & 24.50 & 3.58 & 20.70 & 24.50 & 1.30 & 20.80 \\
\hline & 6 & 5.62 & 2.70 & 4.38 & 4.38 & 2.70 & 1.56 & 4.38 \\
\hline \multirow[t]{2}{*}{10} & 1 & 0.00 & 4.80 & 2.90 & 4.10 & 4.80 & 1.18 & 4.16 \\
\hline & 2 & 3.84 & 0.00 & 3.28 & 1.34 & 0.00 & 1.34 & 1.32 \\
\hline Avg. & & 7.85 & 9.19 & 5.25 & 12.17 & 9.19 & 2.34 & 12.20 \\
\hline
\end{tabular}


Table 3. Growing stages of padty crops.

\begin{tabular}{cl}
\hline \multicolumn{1}{c}{ Growing stage } & \multicolumn{1}{c}{ Period } \\
\hline Ia: Puddling and transplanting & June 15-June 25 \\
Ila: Tillering & June 26-July 24 \\
IIIa: Mid summer drainage & July 25-Aug.10 \\
IVa: Growing & Aug.11-Aug.31 \\
Va: Flowering & Sep.1-Sep.10 \\
Vla: Mat.11ring & Sep.11-Oct.6 \\
VIlb: Ripening & Oct.7-Oct.31 \\
\hline
\end{tabular}

a : irrigation period $\quad b$ : no irrigation period

association of farmers for operating and maintaining the irrigation system. In usual, when there is rainfall, the irrigation water is not supplied onto paddy crops. However, in a certain stage such as the growing and the flowering stages, even though there is rainfall, the irrigation water is also applied for anticipating the adequate water due to the sensitivity of paddy crops for the shortage water on this condition.

Table 4. Evaporation Ratio.

\begin{tabular}{cccccccccccc}
\hline \multicolumn{1}{c}{ Junc } & \multicolumn{3}{c}{ July } & \multicolumn{4}{c}{ August } & \multicolumn{3}{c}{ September } & \multicolumn{2}{c}{ October } \\
\hline $\mathrm{b}$ & $\mathrm{c}$ & $\mathrm{a}$ & $\mathrm{b}$ & $\mathrm{c}$ & $\mathrm{a}$ & $\mathrm{b}$ & $\mathrm{c}$ & $\mathrm{a}$ & $\mathrm{b}$ & $\mathrm{c}$ & $\mathrm{a}$ \\
1.08 & 1.08 & 1.08 & 1.03 & 1.01 & 1.09 & 1.07 & 1.16 & 1.17 & 1.30 & 1.40 & 1.22 \\
\hline
\end{tabular}

Where, a : the first ten days of the month

b : the second ten days of the month

$\mathrm{c}:$ the third ten days of the month

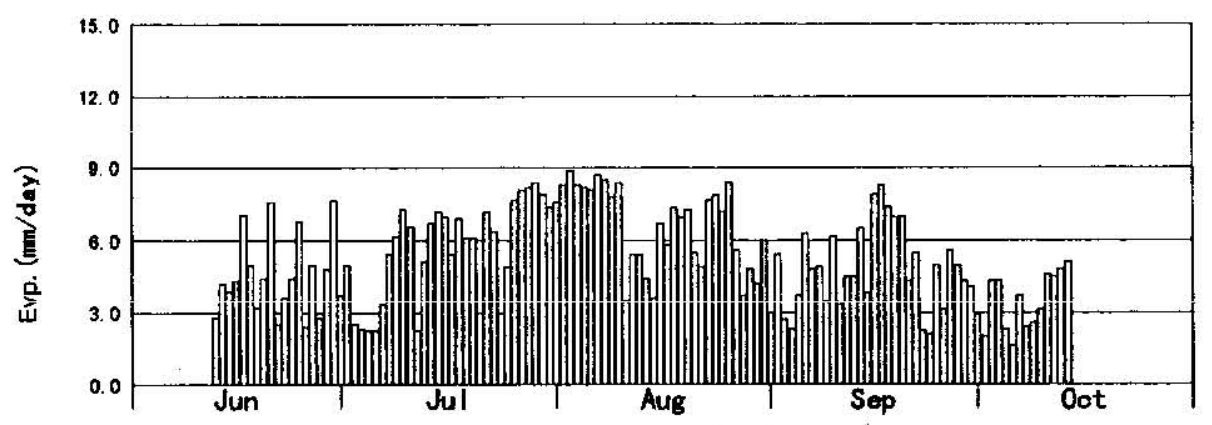

Fig. 3. Evapotranspiration from paddy fields (1995). 


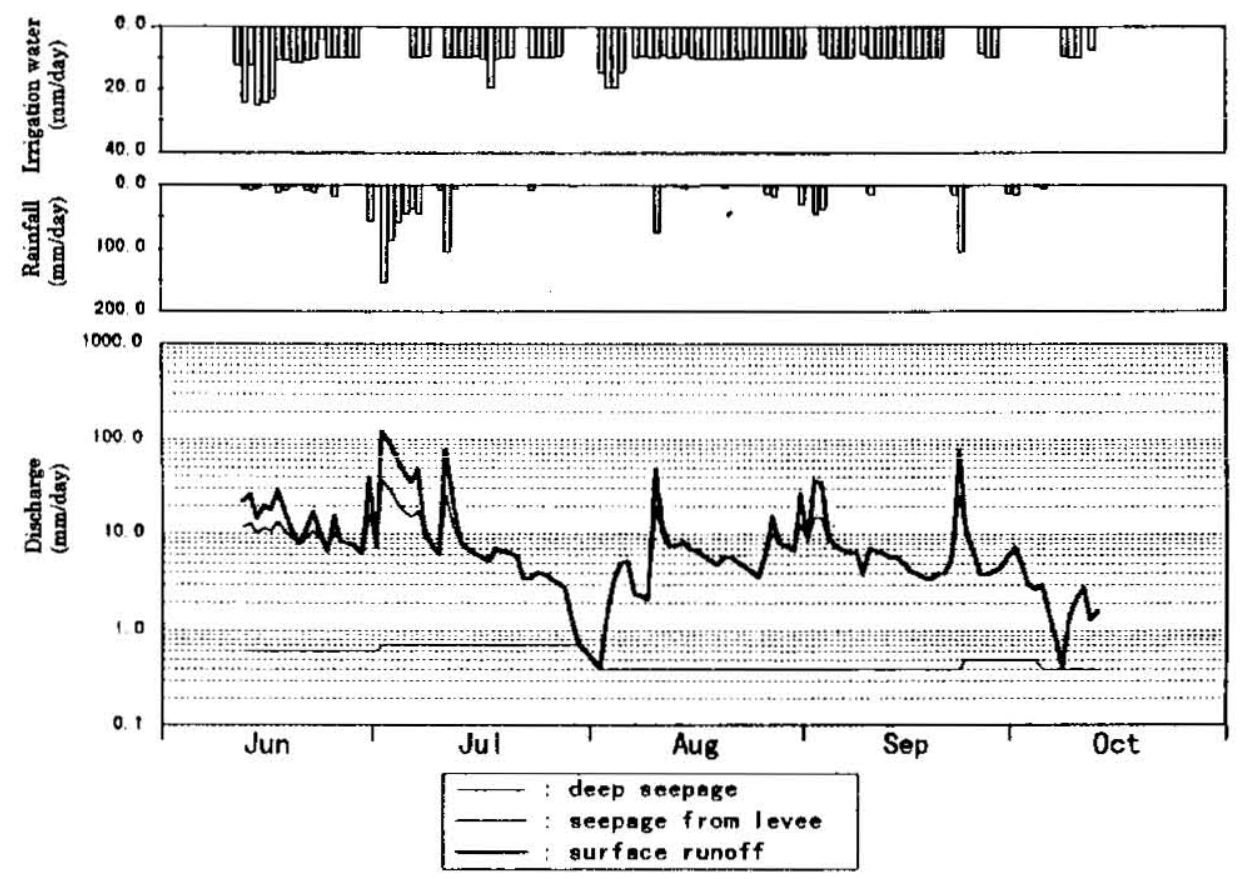

Fig. 4. Discharge from paddy fields into drainage canal (1995).

The daily evapotranspiration was obtained from daily evaporation data calculated by Penman Method using the computer program multiplying by the evaporation ratio. Sato (1960) proposed the evaporation ratio as shown in Table 4. Fig. 3 presents the calculated evapotranspiration. It can be seen that the value of evapotranspiration fluctuated during an irrigation period. In the case of no rainfall between the third ten days of July and the first ten days of August, the values of evapotranpiration tended to increase up to $8.36 \mathrm{~mm} /$ day. It is suggested the irrigation water had to be concerned in this condition. The average of evapotranspiration was around $5.25 \mathrm{~mm} /$ day through paddy planting season.

Fig. 4 shows that the water discharge from paddy fields into drainage canal as return flow has large fluctuation. If there was no a rainfall, the return flow would decrease about less than $10 \mathrm{~mm} /$ day, but if there was much rainfall, the return flow would reach to $100 \mathrm{~mm} /$ day or so. The averages of simulated discharge of surface runoff, levee seepage and deep secpage from paddy fields into drainage canal were around $4.54 \mathrm{~mm} /$ day, $6.73 \mathrm{~mm} /$ day and $0.52 \mathrm{~mm} /$ day, respectively. The return flow in the drainage canal was around $11.79 \mathrm{~mm} /$ day as the total of those discharges during paddy irrigation season. The similar phenomenon was pointed in the previous report (Ikushima and Kuroda, 1973). 


\section{Analysis of Water Quality}

Net substance concentration

The measuring items of water quality were total nitrogen $(T N)$, electric conductivity $(E C)$ and chemical oxygen demand $(C O D)$. The net substance concentration analysis was implemented for evaluating the status of water quality in the paddy irrigation system. The analyses was conducted by examining the water quality in resource at the Point $P$ in the creek as well as in return flow at the Point $D$ in the drainage canal as given in equation (4).

$$
\Delta C=\text { Cout }- \text { Cin }
$$
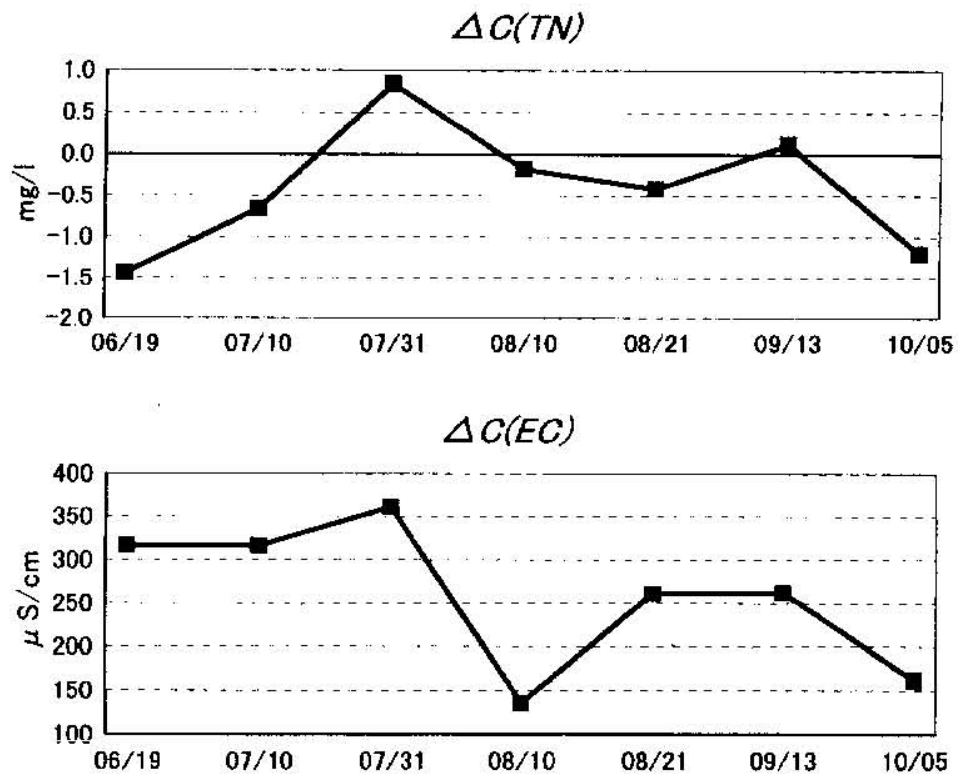

$\triangle C(C O D)$

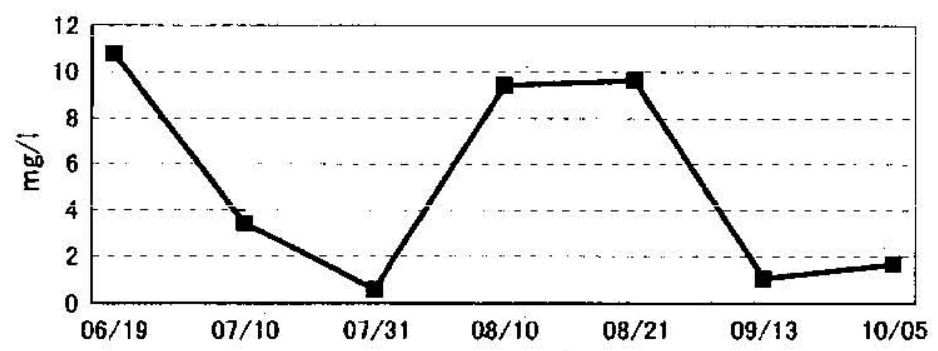

Fig. 5. Observed values of net substance concentration (1995). 
Where $\Delta C$, Cin and Cout are the net substance concentration, the input substance concentration at the Point $P$ and the output substance concentration at the Point $D$, respectively. The dimension of mcasuring items are $C(T N)(m g /), C(E C)(\mu S / \mathrm{cm})$ and $C(C O D)(m g /)$.

The observed values of $\triangle C(T N), \triangle C(E C)$ and $\triangle C(C O D)$ are shown in Fig. 5 . Usually, the purification process of total nitrogen occurs in the system except just after the period of fertilizer application. As nitrates are held under the condition of poor aeration due to flooding water, denitrification process (nitrates can be changed to gaseous nitrogen) accelerates the action of vanishing nitrogen from the flooded soil (Loehr, 1977). Such phenomenon always occurs in paddy fields. These facts do not conflict with the negative values of $\triangle C(T N)$ in paddy irrigation season (for example on 06/11,07/10, 08/21 and so on) as shown in Fig. 5.

In this area, the first period of fertilizer application was around July 31 st and the second period of fertilizer application was around August 10th. The observed value of $\triangle C(T N)$ was positive just after the first period of fertilizer application (July 31st). It would relate to the process of nitrogen adsorption in soil within few days after fertilizer application. At such time, the nitrogen concentration in return flow was increased. The observed value of $\triangle C(T N)$ at the second period of fertilizer application (August 10th) in Fig. 5 tended to decrease due to the abundance of rainfall around $74.5 \mathrm{~mm} /$ day as shown in Fig. 4. But this phenomenon was not caused by the purification case. It related to process of the excess water in drifting out nitrogen into the drainage canal. This fact will be discussed in the following part on the analysis of net effluent load.

The positive values of $\triangle C(E C)$ and $\triangle C(C O D)$ in Fig. 5 mean that the polluted action occurred in the paddy irrigation system. The observed values $\triangle C(E C)$ and $\triangle C(C O D)$ in the beginning of irrigation season were rather higher than other period. These values were also higher than the restricted index for irrigation water $(300 \mu \mathrm{S} / \mathrm{cm}$ for $\mathrm{C}(E C), 6$ $m g / l$ for $\mathrm{C}(C O D))$. Abundant rainfall as shown in Fig. 4 caused the $\triangle C(E C)$ to decrease, for example on August 10th, vice versa for $\triangle C(C O D)$ in Fig. 5. The same phenomena were found in the previous report (Tabuchi, 1977).

\section{Net effluent load}

The effluent load analysis was used for evaluating the status of water quality. The net effluent load $(\Delta L)$ is given in equation (5).

$\begin{array}{ll} & \Delta L=\text { Lout }- \text { Lin } \\ \text { in which, } & \text { Lout }=(\text { qout } \cdot \text { Cout }) / A \\ & \text { Lin }=(\text { qin } \cdot \text { Cin }) / A\end{array}$

Where, qin and qout are the irrigation water $(U / s)$ and the return flow from paddy fields $(U / S)$, respectively. Symbol $A$ is the area of paddy fields (hectare). Lin is the inflow load, Lout is the outflow load and the dimension of measuring items are $\Delta L(T N)(\mathrm{mg} / \mathrm{s} / \mathrm{ha})$, $\Delta L(E C)(\mu \mathrm{S} / \mathrm{cm} \cdot \mathrm{l} / \mathrm{s} / \mathrm{h} a)$ and $\Delta L(C O D)(m \mathrm{mg} / \mathrm{s} / \mathrm{ha})$.

Fig. 6 shows the obtained values of $\Delta L(T N), \Delta L(E C)$ and $\Delta L(C O D)$. From Fig. 6 , it can be seen that the obtained values of $\Delta L(T N)$ are generally negative except at the first period of fertilizer application (around July 31st) and at the second period of fertilizer application (around August 10th). These negative evidences show that the purification case occurring in the system was reasonable except fertilizer application periods as 

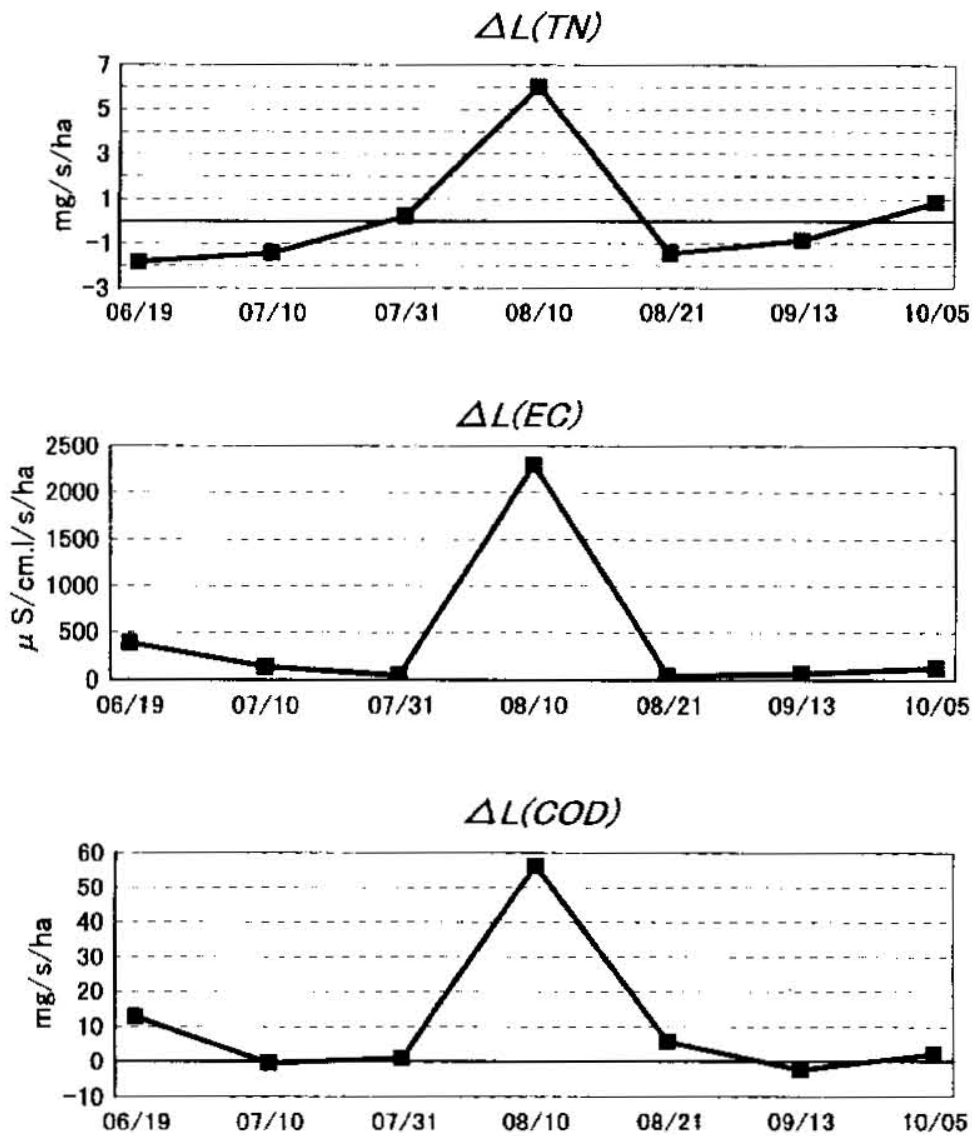

Fig. 6. Obtained values of net effluent load (1995)

mentioned before. The value of $\triangle \mathrm{C}(T N)$ on July 31st in Fig. 5 was so high due to the polluting action in the paddy irrigation system. But the value of $\triangle L(T N)$ in Fig. 6 tended to decrease due to the small amount of Qoutd because of no rainfall on July 3ist as shown in Fig. 4. On the contrary, the value of $\triangle L(T N)$ on August 10th in Fig. 6 was increased due to the abundant rainfall as shown in Fig. 4. The values of $\Delta L$ for concerning items of $T N, E C$ and $C O D$ were low on the other measuring dates except on August 10 th, because of the lack rainfall in these dates. The values of $\Delta L$ for $E C$ and $C O D$ were positive during the irrigation period. It means that in this period the polluting action occurred in the paddy irrigation system. Furthermore, the abundant rainfall on August 10th caused also increasing of $\Delta L(E C)$ and $\Delta L(C O D)$.

The study area of 10.3 ha was consisted of many paddy plots (more than 40 plots). Farmers individually applied the fertilizer for their plots. Each period was, therefore, spread for several days. The total dates were around 14 days in this area. Table 5 shows the formulated values of each item on $\Delta L(T N), \Delta L(E C)$ and $\Delta L(C O D)$ in the normal days 
Table 5. Fommulated values of $\Delta L$ on the normal days and on the restricted days during fertilizer application.

\begin{tabular}{ccc}
\hline Itens & Normal days & $\begin{array}{c}\text { Restricted days during fertilizer application } \\
\text { (around July 31st and around August 10th) }\end{array}$ \\
\hline$\Delta(T N)$ & $-1.4(\mathrm{mg} / \mathrm{s} / \mathrm{ha})$ & $0.0737 \mathrm{X}+0.49(\mathrm{mg} / \mathrm{s} / \mathrm{ha})$ \\
$\Delta L(E C)$ & $131.3(\mathrm{mS} / \mathrm{cm} \cdot \mathrm{l} / \mathrm{s} / \mathrm{ha})$ & $27.46 \mathrm{X}+184(\mathrm{HS} / \mathrm{cm} \cdot \mathrm{s} / \mathrm{ha})$ \\
$\Delta L(C O D)$ & $3.1(\mathrm{mg} / \mathrm{s} / \mathrm{ha})$ & $0.693 \mathrm{X}+4.64(\mathrm{mg} / \mathrm{s} / \mathrm{ha})$ \\
\hline
\end{tabular}

$\mathrm{X}$ : rainfall(mm/day)

and in the restricted days during the period of fertilizer application. Each item was strongly affected by rainfall during fertilizer application periods. The values of $\Delta L$ were decreased for example on July 31st in spite of fertilizer application period, because of no rainfall on that day. But in rainy day during fertilizer application period, $\Delta L$ increased linearly with respect to the amount of rainfall for example on August 10th in Fig. 6.

\section{CONCLUSIONS}

The water balance and the concerning components were clarified using a complex tank model as shown in Table 2. The model was very useful for simulating the water cyclic, especially in performing the unknown parameters of return flow. The return flow had severe impacts on water quality, although it improved the efficiency of water use.

The net substance concentration analysis showed that the purification process of total nitrogen (TN) occurred in the paddy irrigation system, except during the periods of fertilizer application. The electric conductivity $(E C)$ and the chemical oxygen demand (COD) increased in the system. These phenomena were also proven by the net effhent. load analysis. Relationship between net effluent load and rainfall in periods both of normal days and restricted days during fertilizer application in the paddy irrigation system could be formulated as shown in Table 5. Generally, the water condition in this area was suitable for paddy cuilivation. However, it was important to monitor the values of $T N, E C$ and $C O D$, because in certain days the values were higher than the restricted indexes for paddy crops.

\section{REFERENCES}

Ikusina, Y. and M. Kuroda 1973 On the Water Budgel after Land Readjustinent for Heavy Clay Soil Paddy Ficld (lose 1o Creek. Bulletin of Fac. of Agriculture Saga Lniversity, 35: 31-49. (in Japanese).

Kuroda, M., T. Fukuda and F. Nurrochmad 1992 irrigation Return Flow Mechanism and Water Quality in Jow Lying Paddy Arca. Proc. of the 1992 International Symposium of Land Reclamation: Advances in Research and Techrology, ASAE. pp 40-49.

Loehr, R. C. 1977 Pollution Control for Agriculture. Academic Press, Ine. New York. pp. 34-35

Sato, M. 1960 Study on Micro Climate for Paddy Ficld and Rice Cultivation in Japan. Bulletin of Kyushu Agricultural Research Centcr. 6(4): 259-364 (in Japanese).

Tabuchi, T.(cd.) 1977 Marual of Water Qualities for Agricultural Engincers. The Japanese Society of Irrigation, Drainage and Reclamation Engineering. pp. 31-45 (In Japanese). 